\title{
2,3 Diphosphoglycerate in Parkinson's disease
}

\author{
B. A L E V I Z OS ${ }^{1}$ A N D C. STEF A N IS \\ From the Department of Psychiatry, The Athens University, \\ Aeginition Hospital, Athens, Greece
}

SYNOPSIS The red cell 2,3 DPG, the most important factor for oxygen delivery in the tissues, was found to be increased in Parkinsonism patients compared with controls. The aging process seems not to be a factor in the increased 2,3 DPG concentration. Other factors relevant to raised 2,3 DPG level such as physical activity, increased oxygen requirements, and metabolic changes are discussed.

2,3 Diphosphoglycerate (2,3 DPG) is known to play an important role in the adaptive response of the red blood cell to hypoxia. Its increased concentration causes a shift of the oxygen dissociation curve to the right and this allows more oxygen to be released from the oxyhaemoglobin molecule at the tissue level (Miller et al., 1970b).

High concentrations of red cell 2,3 DPG occur in patients with hypoxic diseases (Eaton and Brewer, 1968; Oski et al., 1969), in high altitude residents (Lenfant et al., 1968), during exercise (Eaton et al., 1969b), after administration of androgens (Gorshein et al., 1974), in thyrotoxicosis (Snyder and Reddy, 1970), and in red cell pyruvate kinase deficiency (Mourdjinis et al., 1969).

On the other hand, Parkinson's disease is associated with biological factors which may affect the 2,3 DPG concentrations. The respiratory capacity is reduced in these patients because of postural abnormalities and rigidity (Mier, 1967). The associated hypoventilation may thus lead to changes of $\mathrm{pH}$, which is another factor affecting the 2,3 DPG concentration (Bellingham et al., 1971). Furthermore, tremor and rigidity may be accompanied by an increased metabolic rate, which, it is suggested, accounts for the increase of 2,3 DPG in hyperthyroidism and after the administration of androgens (Gorshein et al., 1974). Finally, slight abnormalities in glucose metabolism have been reported in Parkinson's disease

1 Address for reprints: Department of Psychiatry, Athens University, Aeginition Hospital, 74 Vass. Sophias Str, Athens, Greece.

Present address and for reprints and correspondence: Institute of Psychiatry, Department of Psychiatry, De Crespigny Park, Denmark Hill, London, SE5 8AF.

(Accepted 27 May 1976.)
(Lipman et al., 1974) and 2,3 DPG is known to be involved in the regulation of the glycolytic process (Askari and Rao, 1968; Rose, 1968). As all these factors may be instrumental in changing 2,3 DPG and in the context of trends viewing Parkinson's disease as a biochemical disease not confined to the central nervous system (Barbeau et al., 1975), we thought it of interest to investigate possible changes in 2,3 DPG concentration in patients with Parkinson's disease. Additionally, in some patients, adenosine triphosphate (ATP) concentration in red cells and the red cell glucose6-phosphate dehydrogenase (G-6-PD) activity were determined. ATP is a less important factor in the red cell's affinity for oxygen and G-6-PD plays an important role in the anaerobic glycolysis (hexose monophosphate shunt).

\section{METHODS}

Seventeen patients with Parkinson's disease (nine males, eight females) were selected for the study. They ranged in age from 37 to 75 years with a mean of 60.4 years \pm SD 11 . Most were ambulatory and only four were confined to a wheelchair. Most of the patients were drug free and few were on anticholinergic drugs. Patients under treatment with levodopa were excluded.

The same number of healthy volunteers served as controls. Their ages ranged from 24 to 73 years with a mean of 38.6 years \pm SD 16 and differed significantly from the patient group $(\mathrm{P}<0.001)$.

Blood samples were taken immediately after admission from the drug free patients and one week after their previous medication was stopped from the patients on anticholinergic treatment. 
Haemoglobin and haematocrit were determined according to standard haematological techniques. Measurements of 2,3 DPG were carried out according to the chromatropic acid method of Bartlett (1959) with the modifications of Eaton et al. (1969a): one volume of packed red cells washed three times in isotonic saline was mixed with two volumes of cold $6.7 \%$ trichloracetic acid. The mixture was stored frozen for an average of seven days and $0.1 \mathrm{ml}$ of the protein free extract was added to $3.9 \mathrm{ml}$ of $0.01 \%$ chromatropic acid in concentrated sulphuric acid. The mixture was incubated at $100^{\circ} \mathrm{C}$ for 135 minutes and the optical density was read in $695 \mathrm{~nm}$ in a Spectronic 88 spectrophotometer. 2,3 DPG concentration was estimated by standard curve and expressed in $\mu \mathrm{mol} / \mathrm{ml}$ red blood cells. As the haemoglobin was known, the concentration per gram was calculated. Normal values were established on 17 healthy volunteers (nine males, eight females) and found to be $3.72-5.04 \mu \mathrm{mol} / \mathrm{ml}$ red cells.

ATP was determined according to Dennemann's method (1961). The reagents used were supplied by Boehringer Manheim in the form of a test kit for ATP determination (Cat. No 15979).

G-6-PD activity was determined by the method of Kornberg and Horecker (1955).

\section{RESULTS}

The results are shown in Tables 1,2 , and 3. Sex, age, and values of haematocrit $(\mathrm{Ht})$, haemoglobin (Hb), 2,3 DPG, ATP, and G-6-PD for each con- trol subject and each patient are tabulated in Tables 1 and 2 respectively. The comparative average values from the two groups for all these parameters are shown in Table 3 .

The results showed that the 2,3 DPG, expressed in $\mu \mathrm{mol}$ per $\mathrm{ml}$ of red cells or $\mu \mathrm{mol}$ per $\mathrm{g}$ of haemoglobin, is raised in the patient group $(\mathrm{P}<0.001)$, while there is no significant difference between the two groups for $\mathrm{Ht}, \mathrm{Hb}$, ATP, and G-6-PD.

In correlating age and 2,3 DPG concentration in the control group (Fig. 1), it was found that 2,3 DPG levels do not increase with advancing age. By contrast with the control group, a negative correlation $(r-0.6, \mathrm{P}<0.01)$ has been found to exist between age and 2,3 DPG levels in the patient group (Fig. 2).

\section{DISCUSSION}

2,3 DPG is produced as an intermediate in glycolysis from 1,3 DPG in the presence of the enzyme 2,3 diphosphoglycerate mutase and is hydrolysed to 3-phosphoglycerate and inorganic phosphate by the enzyme 2,3 diphosphoglycerate phosphatase (Rapoport, 1965). Its concentration within the cell depends on a variety of factors such as $\mathrm{pH}$, phosphate, pyruvate, triiodothyronine and the activity of 2,3 DPG mutase, while 2,3 DPG itself plays a regulatory role in controlling glycolysis (Askari and Rao, 1968; Rose, 1968). The more 2,3 DPG is bound by deoxyhaemoglobin the less are the inhibitory effects on hexokinase and 2,3 DPG

T A B L E 1

SEX, AGE, HT, HB, 2,3 DPG, ATP, AND G-6-PD IN HEALTHY VOLUNTEERS

\begin{tabular}{|c|c|c|c|c|c|c|c|c|}
\hline No. & Sex & $\begin{array}{l}\text { Age } \\
(y r)\end{array}$ & $\begin{array}{c}H t \\
(\%)\end{array}$ & $\begin{array}{c}H b \\
(g / d l)\end{array}$ & $\begin{array}{c}2,3 \mathrm{DPG} \\
(\mu \mathrm{mol} / \mathrm{mlRBC})\end{array}$ & $\begin{array}{c}2,3 \mathrm{DPG} \\
(\mu \mathrm{mol} / \mathrm{gHb})\end{array}$ & $\begin{array}{c}A T P \\
(n m o l / m l R B C)\end{array}$ & $\begin{array}{c}G-6-P D \\
(m U / m l R B C)\end{array}$ \\
\hline 1 & $\mathbf{M}$ & 51 & 50.5 & 15.3 & 4.920 & 16.19 & 1230.89 & 1517.43 \\
\hline 2 & $F$ & 30 & 41.8 & 13.7 & 4.704 & 14.35 & 1455.21 & 1580.59 \\
\hline 3 & $\mathbf{M}$ & 25 & 48 & 16.8 & 4.470 & 12.77 & 1396.75 & 1846.80 \\
\hline 4 & $\mathbf{M}$ & 24 & 53.8 & 16.5 & 4.680 & 15.25 & 1303.94 & 1860.60 \\
\hline 5 & $F$ & 29 & 43.8 & 14.3 & 4.500 & 13.77 & 1955.30 & 1363.43 \\
\hline 6 & $F$ & 39 & 41.7 & 13.5 & 4.260 & 13.16 & 1276.18 & 1402.90 \\
\hline 7 & $\mathbf{M}$ & 32 & 48 & 17.5 & 4.560 & 12.50 & 1206.20 & 2247 \\
\hline 8 & $F$ & 29 & 43 & 14.4 & 4.620 & 13.79 & 1424.93 & 1847 \\
\hline 9 & $\mathrm{M}$ & 70 & 44 & 15.1 & 5.040 & 14.70 & 1533.82 & 2031.56 \\
\hline 10 & $\mathbf{M}$ & 28 & 40 & 12.3 & 4.680 & 15.25 & 1365.30 & 2047 \\
\hline 11 & $\mathbf{M}$ & 31 & 43.3 & 14.5 & 4.212 & 12.57 & 1374.04 & 1919.40 \\
\hline 12 & $\mathbf{M}$ & 23 & 47.9 & 16 & 4.116 & 12.32 & 1418.14 & 1542.30 \\
\hline 13 & $\mathrm{~F}$ & 62 & 43 & 13.5 & 4.056 & 12.91 & & \\
\hline 14 & $\mathbf{M}$ & 39 & 47.4 & 15.9 & 3.756 & 11.19 & & \\
\hline 15 & $\mathrm{~F}$ & 43 & 41 & 13.6 & 3.720 & 11.21 & & \\
\hline 16 & $\mathbf{M}$ & 29 & 43 & 15.6 & 4.320 & 11.90 & & \\
\hline 17 & F & 73 & 47.3 & 15.4 & 4.236 & 13.01 & & \\
\hline
\end{tabular}


T A B L E 2

SEX, AGE, HT, HB, 2,3 DPG, ATP, AND G-6-PD IN PATIENTS WITH PARKINSON'S DISEASE

\begin{tabular}{|c|c|c|c|c|c|c|c|c|}
\hline No. & Sex & $\begin{array}{l}\text { Age } \\
(y r)\end{array}$ & $\begin{array}{c}H t \\
(\%)\end{array}$ & $\underset{(g / d l)}{H b}$ & $\begin{array}{c}2,3 \mathrm{DPG} \\
(\mu \mathrm{mol} / \mathrm{mlRBC})\end{array}$ & $\begin{array}{c}2,3 \mathrm{DPG} \\
(\mu \mathrm{mol} / \mathrm{gHb})\end{array}$ & $\begin{array}{c}A T P \\
(n m o l / m l R B C)\end{array}$ & $\begin{array}{c}G-6-P D \\
(m U / m l R B C)\end{array}$ \\
\hline 1 & $\mathbf{F}$ & 66 & 47 & 17.2 & 5.256 & 14.36 & 1450.08 & 1956.90 \\
\hline 2 & $\mathbf{F}$ & 62 & 42 & 16 & 5.376 & 14.11 & 1956.28 & \\
\hline 3 & $\mathbf{M}$ & 60 & 48 & 17.6 & 5.940 & 16.20 & 1143.30 & 1893.05 \\
\hline 4 & $\mathbf{F}$ & 64 & 44.5 & 14.7 & 6.444 & 17.70 & 1287.10 & 1582.64 \\
\hline 5 & $\mathbf{F}$ & so & 45.5 & 13.9 & 5.520 & 18.07 & 1005.01 & 1693.98 \\
\hline 6 & $\mathbf{M}$ & 63 & 44.5 & 14.7 & 5.220 & 15.80 & 1237.21 & 1660.11 \\
\hline 7 & $\mathbf{F}$ & 37 & 45 & 12.8 & 6.120 & 21.51 & 1262.93 & 1658.08 \\
\hline 8 & $\mathbf{F}$ & 63 & 44 & 14.8 & 5.040 & 14.97 & 1654.91 & 2277.81 \\
\hline 9 & $\mathbf{F}$ & 67 & 43 & 13.3 & 5.160 & 16.68 & 1208.09 & 1483.23 \\
\hline 10 & $\mathbf{M}$ & 52 & 46 & 17.2 & 5.340 & 14.28 & 1313.69 & \\
\hline 11 & $\mathbf{M}$ & 73 & 43 & 15.2 & 5.040 & 14.25 & 1517.86 & 2181.89 \\
\hline 12 & $\mathbf{M}$ & 68 & 44 & 15 & 5.160 & 15.36 & 1584.27 & 2182.67 \\
\hline 13 & $\mathbf{M}$ & 75 & 51 & 17.7 & 4.200 & 12.10 & & 1752.72 \\
\hline 14 & $\mathbf{F}$ & 36 & 43.5 & 16.3 & 6.168 & 16.56 & & \\
\hline 15 & $\mathbf{M}$ & 69 & 56.5 & 18 & 5.352 & 16.80 & & \\
\hline 16 & $\mathbf{M}$ & 59 & 44.8 & 17.6 & 6.180 & 15.55 & & \\
\hline 17 & $\mathbf{M}$ & 63 & 44 & 14.6 & 5.520 & 16.63 & & \\
\hline
\end{tabular}

T A B L E 3

VALUES OF AGE, HT, HB, 2,3 DPG, ATP, AND G-6-PD IN NORMAL SUBJECTS AND IN PATIENTS WITH PARKINSON'S DISEASE

\begin{tabular}{|c|c|c|c|c|c|c|c|}
\hline & $\begin{array}{l}\text { Age } \\
(y r)\end{array}$ & $\begin{array}{c}H t \\
(\%)\end{array}$ & $\begin{array}{c}H b \\
(g / d l)\end{array}$ & $\begin{array}{c}2,3 \mathrm{DPG} \\
(\mu \mathrm{mol} / \mathrm{mlRBC})\end{array}$ & $\begin{array}{c}2,3 \mathrm{DPG} \\
(\mu \mathrm{mol} / \mathrm{gHb})\end{array}$ & $\begin{array}{c}A T P \\
(n m o l / m l R B C)\end{array}$ & $\begin{array}{c}G-6-P D \\
(m U / m l R B C)\end{array}$ \\
\hline $\begin{array}{l}\text { Normal cases (No.) } \\
\text { Mean } \\
\pm \text { SD } \\
\text { Range } \\
\text { Patient cases (No.) } \\
\text { Mean } \\
\pm \text { SD } \\
\text { Range }\end{array}$ & $\begin{array}{l}17 \\
38.65 \\
16 \\
23-73 \\
17 \\
60.41 \\
11 \\
36-75\end{array}$ & $\begin{array}{c}17 \\
45.15 \\
3.74 \\
40-53.8 \\
17 \\
45.66 \\
3.52 \\
42-56.5\end{array}$ & $\begin{array}{c}17 \\
14.93 \\
1.39 \\
12.3-16.8 \\
17 \\
15.68 \\
1.63 \\
12.8-18\end{array}$ & $\begin{array}{c}17 \\
4.403 \\
0.370 \\
3.720-5.040 \\
17 \\
5.473 \\
0.551 \\
4.200-6.444\end{array}$ & $\begin{array}{c}17 \\
13.34 \\
1.43 \\
11.19-16.19 \\
17 \\
15.94 \\
2.07 \\
12.10-21.51\end{array}$ & $\begin{array}{c}12 \\
1411.72 \\
195.68 \\
1206.2-1955.3 \\
12 \\
1355.07 \\
203.11 \\
1005.01-1956.28\end{array}$ & $\begin{array}{c}12 \\
1768 \\
280.07 \\
1363.43-2247 \\
11 \\
1847.55 \\
270.14 \\
1483.23-2277.81\end{array}$ \\
\hline Significance & $P<0.001$ & NS & NS & $P<0.001$ & $P<0.001$ & NS & NS \\
\hline
\end{tabular}

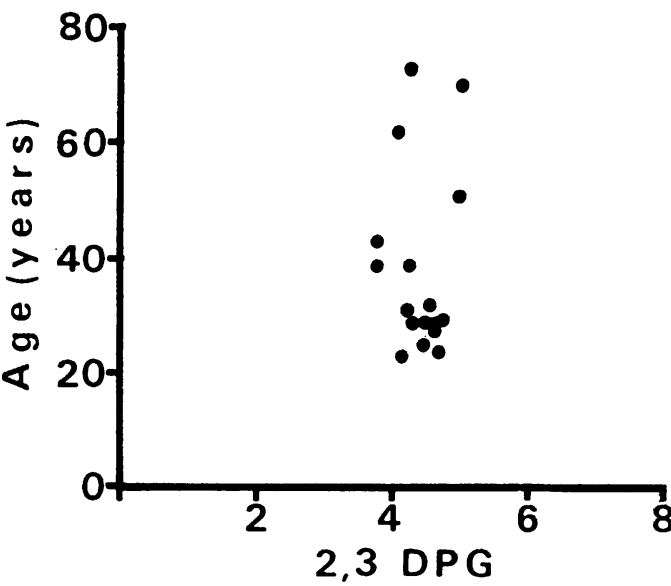

FIG. 1 2,3 DPG expressed as umol per $\mathrm{ml}$ red cells, plotted against age, in normal subjects.

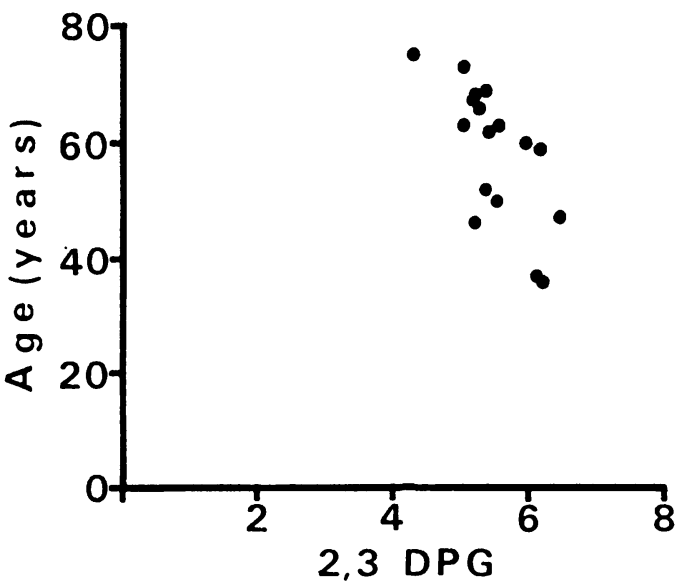

FIG. 2 2,3 $\mathrm{DPG}(\mu \mathrm{mol} / \mathrm{ml} \mathrm{RBC})$, plotted against age, in Parkinsonism patients. 
mutase promoting further glycolysis and 2,3 DPG production.

In our study, the red cell 2,3 DPG concentration was found to be significantly raised in Parkinsonism patients compared with control subjects. In view of these results and before any attempt is made to relate them to the biological process underlying Parkinson's disease, the following factors have to be considered:

\section{AGE}

Although the mean age of our patients was higher than that of our control subjects, no positive correlation was found between 2,3 DPG and age, suggesting that the aging process does not substantially affect 2,3 DPG levels. A significant negative correlation between age and 2,3 DPG has, however, been demonstrated in the patient group, which indicates that in younger patients the 2,3 DPG concentration tends to be higher. Assuming that the younger the patient the more uncontaminated the disease is by other physical symptoms, this finding may support the view that increased 2,3 DPG activity is more closely related to the biochemical disturbance underlying Parkinsonism itself than to secondary biological complication arising from it and from age.

\section{PHYSICAL ACTIVITY}

2,3 DPG levels may reflect the degree of physical activity since it is known that exercise results in raised 2,3 DPG levels. Physical activity was not assessed in our study groups. It is reasonable, however, to assume that, although our Parkinsonism patients were not confined to bed, by no means could they be considered as being physically overactive.

\section{OXYGEN REQUIREMENTS}

As the oxygen supply system is closely coupled with the oxygen requirements of physical activity, the muscular rigidity and tremor leading to an increased metabolic rate could account for the raised 2,3 DPG in our patients. This could be in agreement with the finding of raised 2,3 DPG levels in hyperthyroidism, although the rise in this case has been attributed to a specific action of thyroid hormone on glycolysis (Miller et al., 1970a).

Postural abnormalities, rigidity, lack of exercise, and, possibly, other neurological deficits in patients with Parkinsonism may result in a limitation of respiratory excursion and diminution of respiratory function. Paulson and Tafrate (1970) who measured the pulmonary function in Parkinsonism patients before and after L-dopa treatment, found a marked increase in minute ventilatory volume with a less marked change in vital capacity. The hypoventilation consequent to these changes may lead to hypoxia and this could well explain the raised red cell concentration of 2,3 DPG. In disorders of oxygen loading as in pulmonary disease, in which there is severe restriction in ventilation, the arterial oxygen desaturation evokes a discharge of erythropoietin and polycythaemia with raised haematocrit (Krantz and Jacobson, 1970). 2,3 DPG is increased and the associated decrease in haemoglobin affinity improves release of oxygen. The simultaneously increased carbon dioxide retention leads to acidosis, which could decrease the 2,3 DPG concentration (Bellingham et al., 1971). Our patients' haematocrit was found not to differ from that of our control subjects. Should hypoxia be held responsible for the raised 2,3 DPG, it is to be assumed that the carbon dioxide retention and the associated acidosis with opposite effect on oxygen release account for the observed variable response in red cell mass and 2,3 DPG concentration in our material.

Bearing in mind the possibility that the raised 2,3 DPG reflects a primary biochemical lesion in Parkinson's disease the following factors could be mentioned:

2,3 DPG is generated by the anaerobic glycolytic pathway. When deoxyhaemoglobin increases the red cell glycolysis is activated and this leads to an increase in 2,3 DPG. Inhibition of 2,3 DPG phosphatase or activation of 2,3 DPG mutase could also lead to increase of 2,3 DPG. Congenital abnormalities in red cell glycolytic enzymes can alter the 2,3 DPG concentration and the oxygen affinity of haemoglobin. It is not known if an abnormality exists in Parkinsonism patients.

Parkinson's disease is characterised by a generalised defect of the dopamine system (Barbeau, 1969; Barbeau et al., 1975). Dopamine administration has been shown to cause hyperglycaemia in animals, probably by interference with the insulin-releasing mechanism in pancreatic beta cells (Hakanson et al., 1967), and an impaired glucose tolerance has been demonstrated in Parkinson's disease (Lipman et al., 1974). Dopamine also plays a part in physiological release of luteinizing hormone, follicle stimulating hormone, prolactin and growth hormone (Cavgnini et al., 1972) probably by hypothalamic involvement, as it is known that the hypothalamus is affected in Par- 
kinson's disease (Forno, 1966). It is not known, to our knowledge, if dopamine insufficiency and/ or hypothalamic involvement may lead to increase of red cell 2,3 DPG. It might be pertinent that androgens as well as thyroxine administration cause an increase of 2,3 DPG.

According to the hypothesis that the syndrome of Parkinsonism results from an imbalance between cholinergic-excitatory and dopaminergicinhibitory actions in favour of cholinergic dominance in the extrapyramidal system, because of dopamine insufficiency (Klawans, 1968, Calne, 1970), the question arises if the raised 2,3 DPG results from an interaction with the red cell acetylcholinesterase. It is possible that a significant portion of the red cell 2,3 DPG and/or ATP is bound to the red cell membrane (Bunn et al., 1971). Acetylcholinesterase is also localised in the red cell membrane. If acetylcholinesterase interacts with 2,3 DPG it could keep it away from the haemoglobin due to an imidazole group in the active site (Egger and Rapoport, 1963). In nucleated red cells (birds) the 2,3 DPG is 'replaced' by phosphoinositol, which is found inside the neurone as well as the acetylcholinesterase. Furthermore, acetylcholine is shown to interact with phosphoinositol turnover (Durell et al., 1969).

It is worth noting that anticholinergic drugs alleviate the Parkinsonism symptomatology and drugs such as chlorpromazine, which prevent the removal of acetylcholinesterase from the red cell, also prevent deterioration of the red cell in storage due to permeability changes (Greig and Gibbons, 1955). In neonatal hypothyroidism (rats) a significant reduction in acetylcholinesterase activity in the cerebral cortex and the hypothalamus has been shown. The administration of thyroxine restored brain growth and enzyme activity to normal (Geel and Timiras, 1967). A similar effect of hypothyroidism and thyroxine on red cell 2,3 DPG has been demonstrated (Grosz and Farmer, 1969, Miller et al., 1970a).

Whether the observed rise in 2,3 DPG level in patients with Parkinsonism is connected with the pathogenesis of the disease or reflects a secondary compensatory mechanism remains to be elucidated. However, further work is needed to investigate the role of 2,3 DPG in relation to different forms of Parkinsonism, specific features and effectiveness of treatment.

\section{REFERENCES}

Askari, A., and Rao, S. N. (1968). Regulations cf AMP deaminase by 2,3 diphosphoglyceric acid: A possible mechanism for the control of adenine nucleotide metabolism in human erythrocytes. Biochimica et Biophysica Acta, 151, 198-203.

Barbeau, A. (1969). Parkinson's disease as a systematic disorder. In Third Symposium on Parkinson's Disease, pp. 66-73. Edited by F. G. Gillingham and I. M. L. Donaldson. Livingstone: Edinburgh.

Barbeau, A., Campanella, G., Butterworth, R. F., and Yamada, K. (1975). Uptake and efflux of ${ }^{14} \mathrm{C}$ dopamine in platelets: evidence for a generalized defect in Parkinson's disease. Neurology (Minneap.), 25, 1-9.

Bartlett, G. R. (1959). Colorimetric assay methods for free and phosphorylated glyceric acids. Journal of Biological Chemistry, 234, 469-471.

Bellingham, A. J., Detter, J. C., and Lenfant, C. (1971). Regulatory mechanisms of hemoglobin oxygen affinity in acidosis and alkalosis. Journal of Clinical Investigation, 50, 700-706.

Bunn, H. F., Ransil, B. J., and Chao, A. (1971). The interaction between erythrocyte organic phosphates, magnesium ion, and hemoglobin. Journal of Bio= logical Chemistry, 246, 5273-5279.

Calne, D. B. (1970). Parkinsonism: Physiology, Phar macology and Treatment. Arnold: London.

Cavgnini, F., Peracchi, M., Scotti, G., Raggi, U.̧ Pontiroli, A. E., and Bana, R. (1972). Effect of L-dopa administration on growth hormone secretio in normal subjects and Parkinsonian patients Journal of Endocrinology, 54, 425-433.

Dennemann, H. (1961). Enzymatische Bestimmung von Adenosintre-phosphat im Vollblut. Zeitschrift für die gesamte experimentelle Medizin, 134, 335340.

Durell, J., Garland, J. T., and Friedel, R. O. (1969). Acetylcholine action: Biochemical aspects. Science, 165, 862-866.

Eaton, J. W., and Brewer, G. J. (1968). The relationship between red cell, 2,3 diphosphoglycerate and levels of hemoglobin in the human. Proceedings of the National Academy of Sciences, 61, 756-760.

Eaton, J. W., Brewer, G. J., and Grover, R. F. (1969a). Role of red cell 2,3 diphosphoglycerate in the adaptation of man to altitude. Journal of Laboratory and Clinical Medicine, 73, 603-609.

Eaton, J. W., Faulkner, J. A., and Brewer, G. (1969b). Response of the human red cell to muscular activity. Proceedings of the Society for Experimental Biology and Medicine, 132, 886-887.

Egger, E., and Rapoport, S. (1963). Role of monocovalent bonds for the holding, activation and release of mitochondrial enzymes. Nature, 200, 240-242.

Forno, L. S. (1966). Pathology of Parkinsonism. Journal of Neurosurgery, 24, 266-277. Suppl. 
Geel, S. E., and Timiras, P. S. (1967). Influence of neonatal hypothyroidism and thyroxine on the acetylcholinesterase and cholinesterase activities in the developing central nervous system of the rat. Endocrinology, 80, 1069-1974.

Gorshein, D., Oski, F. A., and Delivoria-Papadopoules, M. (1974). Effect of androgens on the red cell 2,3 diphosphoglycerate hemoglobin oxygen affinity and red cell mass in mammals. Proceedings of the Society for Experimental Biology and Medicine, 147, 616-618.

Greig, M. E., and Gibbons, A. J. (1955). Possible mechanism of action by which phenothiazine derivates preserve stored blood. American Journal of Physiology, 181, 313-318.

Grosz, H. J., and Farmer, B. B. (1969). Reductionoxidation potential of blood determined by oxygen releasing factor in thyroid disorders. Nature, 222, 875-876.

Hakanson, R., Lundquist, I., and Rerup, C. (1967), On the hyperglycemic effect of dopa and dopamine. European Journal of Pharmacology, 1, 114-119.

Klawans, H. (1968). The pharmacology of Parkinsonism (a review). Diseases of the Nervous System, 29, 805-816.

Kornberg, A., and Horecker, B. L. (1955). Glucose6-phosphate deyhdrogenase. I. Methods in Enzymology, pp. 323-324. Edited by S. P. Colowick and N. O. Kaplan. Academic Press: New York.

Krantz, S. B., and Jacobson, L. O. (1970). Erythropoietin and the Regulation of Erythropoiesis. University of Chicago Press: Chicago.

Lenfant, C., Torrance, J., English, E., Finch, C. A., Reynafarje, C., Ramos, J., and Faura, J. (1968). Effect of altitude on oxygen binding by hemoglobin and organic phosphate levels. Journal of Clinical Investigation, 47, 2652-2656.

Lipman, I. J., Boykin, M. E., and Flora, R. E. (1974).
Glucose intolerance in Parkinson's disease. Journal of Chronic Diseases, 27, 573-579.

Mier, M. (1967). Mechanisms leading to hypoventilation in extrapyramidal disorder, with special reference to Parkinson's disease. Journal of the American Geriatric Society, 15, 230-234.

Miller, W. W., Delivoria-Papadopoulos, M.. Miller, L., and Oski, F. A. (1970a). Oxygen releasing factor in hyperthyroidism. Journal of the American Medical Association, 211, 1824-1826.

Miller, L. D., Oski, F. A., Diaco, J. F., Sugermann, H. J., Gottlieb, A. J., Davidson, D., and DelivoriaPapadopoulos, M. (1970b). The affinity of hemoglobin for oxygen: Its control and in vivo significance. Surgery, 68, 187-195.

Mourdjinis, A., Walters, C., Edwards, M. J., Koler, R. D., Vanderheiden, B., and Metcalfe, J. (1969). Improved oxygen delivery in pyruvate kinase deficiency. Clinical Research, 17, 153.

Oski, F. A., Gottlieb, A. J., Delivoria-Papadopoulos, M., and Miller, W. W. (1969). Red cell 2,3diphosphoglycerate levels in subjects with chronic hypoxemia. New England Journal of Medicine, 280, 1165-1166.

Paulson, G. D., and Tafrate, R. H. (1970). Some 'minor' aspects of Parkinsonism, especially pulmonary function. Neurology (Minneap.), 20, 14-17.

Rapoport, S. (1965). The regulation of glycolysis in mammalian erythrocytes. Essays in Biochemistry, 1, 69-103.

Rose, A. B. (1968). Purification and properties of diphosphoglycerate mutase from human erythrocytes. Journal of Biological Chemistry, 243, 48104820.

Snyder, L. M., and Reddy, W. J. (1970). Mechanism of action of thyroid hormones on erythrocyte, 2,3diphosphoglyceric acid synthesis. Journal of Clinical Investigation, 49, 1993-1998. 